\title{
Multiplex Nested Reverse Transcription-Polymerase Chain Reaction in a Single Tube for Sensitive and Simultaneous Detection of Four RNA Viruses and Pseudomonas savastanoi pv. savastanoi in Olive Trees
}

\author{
Edson Bertolini, Antonio Olmos, María M. López, and Mariano Cambra
}

Departamento de Protección Vegetal y Biotecnología, Laboratorios de Virología e Inmunología y Bacteriología. Instituto Valenciano de Investigaciones Agrarias (IVIA), Apartado oficial, 46113-Moncada, Valencia, Spain.

Accepted for publication 25 September 2002.

\begin{abstract}
Bertolini, E., Olmos, A., López, M. M., and Cambra, M. 2003. Multiplex nested reverse transcription-polymerase chain reaction in a single tube for sensitive and simultaneous detection of four RNA viruses and Pseudomonas savastanoi pv. savastanoi in olive trees. Phytopathology 93:286-292.
\end{abstract}

ABSTRACT

A multiplex nested reverse transcription-polymerase chain reaction (RT-PCR) in a single closed tube was developed for the simultaneous detection of four RNA viruses: Cucumber mosaic virus, Cherry leaf roll virus, Strawberry latent ringspot virus, and Arabis mosaic virus, and the bacterium Pseudomonas savastanoi pv. savastanoi. The method enabled, for the first time, the sensitive and simultaneous detection of RNA and DNA targets from plant viruses and a bacterium, saving time, decreasing risks of contamination, and reducing costs compared with conven- tional monospecific nested amplifications. The method was successfully coupled with colorimetric detection of amplicons using specificprobes to simplify routine detection. Two hundred forty-five olive trees from 15 different cultivars were analyzed by multiplex RT-nested PCR coupled with colorimetric detection. Multiplex nested RT-PCR for viral detection increased the identification of positive trees by $8.1 \%$. An uneven distribution of the viruses was observed in the infected trees. The bacterium was detected in $28.7 \%$ of the analyzed trees by the developed multiplex nested method and by a nested PCR previously developed. This powerful methodology could be applied to other models for the detection of several pathogens in a single assay.

Additional keywords: hybridization, Olea europaea, olive knot, olive viruses.
Sensitive and reliable methods are needed in certification programs for detection and characterization of plant pathogens. Serological methods (enzyme-linked immunosorbent assay) are routinely employed for these purposes because they allow sensitive, specific, and simultaneous analysis of many samples in a single microplate or membrane (7). However, molecular methods based on polymerase chain reaction (PCR) amplification of the nucleic acids $(2,22,32)$ enable greater sensitivity and facilitate the analysis of sequence data. Nevertheless, when the target is in low concentrations, or the samples contain PCR inhibitors, or the pathogens have an uneven distribution as in asymptomatic olive trees (Olea europaea L.), more sensitive detection can be achieved by nested PCR (3). This technique enhances sensitivity, but greatly favors risk of self-contamination when two different tubes are used in the subsequent reactions. To avoid this problem, nested PCR in a single closed tube has been utilized $(17,23)$. The development of a device and a method for nested reverse transcription (RT)-PCR in one tube based on the internal compartmentalization of an Eppendorf tube (21) made the establishment of appropriate conditions for nested PCR simpler.

There is increasing interest in plant pathology for the detection of several targets in a single reaction. Multiplex PCR allows the simultaneous detection of different targets in one assay, saving time, reagents, and reducing costs $(3,10,15,16,18-20,24,26)$. Different plant pathogens, including viruses and bacteria, may infect a single host and their detection facilitates propagation of pathogen-free plant material. However, there are no examples in which several viral RNA and bacterial DNA targets are simultaneously

Corresponding author: M. Cambra; E-mail address: mcambra@ivia.es

Publication no. P-2002-1219-01R

(C) 2003 The American Phytopathological Society detected in a single PCR-based assay. This may be due to technical difficulties of optimizing one-reaction involving many compatible primers and both bacterial DNA and viral RNA targets together as initial samples.

We describe for the first time, a multiplex nested RT-PCR in a single closed tube for the detection of the four RNA viruses and a bacterium frequently infecting olive trees. There is need for high quality nursery plants and consequently various certification programs for olive trees have been started in Italy, Portugal, Spain, Israel, and Argentina. The Spanish Real Decreto 1678/1999 for olive tree production in nurseries established that certified plants must be free of Cucumber mosaic virus (CMV) (29), Cherry leaf roll virus (CLRV) (28), Strawberry latent ringspot virus (SLRSV), and Arabis mosaic virus (ArMV) (27), the olive knot bacterium Pseudomonas savastanoi pv. savastanoi (hereafter $P$. savastanoi) $(6,30)$, and the fungus Verticillium dahliae Kleb. (14).

We have developed a multiplex nested RT-PCR that allows the simultaneous detection of CMV, CLRV, SLRSV, ArMV, and $P$. savastanoi and applied it to analyze asymptomatic nursery plants. The method combines both the sensitivity and the advantages of nested and multiplex techniques. In addition, a colorimetric detection of amplified sequences (amplicons) using specific oligoprobes (3) was used to increase sensitivity and to simplify their routine use in detection.

\section{MATERIALS AND METHODS}

Viral and bacterial isolates. CMV and ArMV were maintained in Nicotiana tabacum cv. Xanthi by mechanical inoculation. CMV isolates M13-96 and P16-97 from serogroup 1 and 2, respectively, were supplied by M. Luis from Servicio de Investigación Agraria (SIA), Zaragoza (Spain), and ArMV (Bio-Rad, Marnes-la-Coquette, France). SLRSV PV0247 and CLRV were supplied by P. 
Gentit, Centre Technique Interprofessionnel des Fruits et Légumes (CTIFL), Bergerac (France), and grafted onto GF 305 Prunus persicae seedlings under controlled conditions. These viral isolates were used as positive controls for RT-PCR reactions as well as during analysis of olive plant material naturally infected with these viruses (3).

Strain 1628-3 of P. savastanoi, from Instituto Valenciano de Investigaciones Agrarias collection, was routinely grown on King's medium $\mathrm{B}$ (11) at $25^{\circ} \mathrm{C}$ for $48 \mathrm{~h}$ and 10 -fold serial dilutions from $2 \times 10^{9} \mathrm{CFU} \mathrm{ml} \mathrm{m}^{-1}\left(\mathrm{OD}_{600 \mathrm{~nm}}=1\right)$ prepared in phosphate-buffered saline (PBS) as controls.

Plant material. A total of 245 olive trees representing 15 different cultivars from the FAO collection at the Centro de Investigación y Formación Agraria (CIFA), Córdoba (Spain), and other selections from different Spanish areas, were used for comparisons. Table 1 shows the cultivars in which a viral or $P$. savastanoi positive detection was noted and the origin of these trees. In addition, samples from nine field-growing adult trees infected with CMV, CLRV, or SLRSV were systematically collected and analyzed in the spring, summer, autumn, and winter of the same year. To analyze viral distribution, the canopies of the trees were divided based on the structure of the main branches into four regions. Healthy olive trees propagated by in vitro tissue culture in a commercial nursery were used as negative controls.

Olive plant extract preparation for analysis of viruses and bacterial enrichment. Samples from olive trees (young shoots $10 \mathrm{~cm}$ long without leaves) collected from four different regions around the canopy of each tree at approximately $2 \mathrm{~m}$ height were prepared for analysis by grinding $1 / 20$ (wt/vol) in PBS, $\mathrm{pH} 7.2$, supplemented with $2 \%$ (wt/vol) polyvinylpyrrolidone (PVP-10) (Sigma, Steinhein, Germany) and $0.2 \%$ (vol/vol) sodium diethyl dithiocarbamate (Sigma). Extracts were prepared in individual plastic bags with a heavy net (Plant Print Diagnostics, Valencia, Spain) using a hammer to disrupt the woody plant material. Extracts from both olive tree samples and positive control plants were used for nucleic acids isolation.
For bacterial analysis, the same type of samples were macerated $1 / 50$ (wt/vol) in PBS, pH 7.2, supplemented with antioxidants (8) as $2 \%(\mathrm{wt} / \mathrm{vol})$ polyvinylpyrrolidone (PVP-10), $1 \%$ mannitol, and $0.1 \%$ citric acid. Extracts were prepared in individual plastic bags as described previously using Stomacher/mix-1 (AES Laboratoire, Combourg, France). The bacteria present in the extract were enriched in $1 / 10$ ( $\mathrm{vol} / \mathrm{vol}$ ) semiselective PVF-1 medium (31) at $25^{\circ} \mathrm{C}$ for $72 \mathrm{~h}$ in agitation (25). The enriched extracts were used for DNA extraction.

Nucleic acids isolation. Viral RNA isolation. RNA isolation from olive plant extracts $(200 \mu \mathrm{l})$ was performed with the RNeasy Plant Mini Kit according to the manufacturer's protocol (Qiagen, Hilden, Germany), eluted with $50 \mu \mathrm{l}$ of RNase-free water, and stored at $-20^{\circ} \mathrm{C}$. Tenfold serial dilutions of isolated CLRV and SLRSV RNA were prepared in RNase-free water for sensitivity comparisons of different RT-PCR methods. In addition, doublestranded RNA (dsRNA) extraction (5) with minor modifications (9) was applied using $10 \mathrm{~g}$ of young shoots and cortical scrapings. Briefly, plant material was ground in liquid nitrogen and mixed with $15 \mathrm{ml}$ of $2 \times$ STE buffer $(20 \mathrm{mM}$ Tris- $\mathrm{HCl}, \mathrm{pH} 8.0,200 \mathrm{mM}$ $\mathrm{NaCl}$, and $2 \mathrm{mM}$ EDTA, $\mathrm{pH} 8.0$ ), $3 \mathrm{ml}$ of $10 \%$ sodium dodecyl sulfate (SDS), $0.3 \mathrm{ml}$ of bentonite $(45 \mathrm{mg} / \mathrm{ml}), 0.3 \mathrm{ml}$ of 2-mercaptoethanol, and $12 \mathrm{ml}$ of phenol-chloroform (1:1, vol/vol). This mixture was shaken for $30 \mathrm{~min}$ and centrifuged at $8,000 \times g$ for $10 \mathrm{~min}$. The aqueous phase was recovered and mixed with Whatman CF11 cellulose (1 g) and absolute ethanol $(4 \mathrm{ml})$. The cellulose was sedimented by centrifuging at $4,000 \times g$ for $15 \mathrm{~min}$. After washing with $17 \%$ ethanol-1× STE, dsRNA was eluted with $1 \times$ STE and precipitated with cold absolute alcohol and $3 \mathrm{M}$ sodium acetate, $\mathrm{pH} 5.5$, for $2 \mathrm{~h}$ at $-70^{\circ} \mathrm{C}$. After centrifugation at $13,000 \times g$ for $30 \mathrm{~min}$, the dsRNA was suspended in $20 \mu \mathrm{l}$ of diethyl procarbonate-treated water.

Bacterial DNA extraction. A simple DNA extraction protocol (13) was applied to enriched olive plant extracts and was used for comparison of the sensitivity of nested PCR and multiplex nested PCR. Briefly, $500 \mu \mathrm{l}$ of sample was centrifuged at $10,000 \times g$ for

TABLE 1. Origin, variety, numbers of olive trees, and test results for the three different polymerase chain reaction (PCR) detection assays

\begin{tabular}{|c|c|c|c|c|c|c|}
\hline Origin & $\begin{array}{l}\text { Number } \\
\text { of trees } \\
\text { analyzed }\end{array}$ & $\begin{array}{l}\text { No. of positive } \\
\text { trees with } \\
\text { different pattern }\end{array}$ & Cultivar & Enrichment nested PCR ${ }^{\mathrm{a}}$ & $\begin{array}{l}\text { Multiplex } \\
\text { RT-PCR }^{\text {b }}\end{array}$ & Multiplex nested RT-PCR ${ }^{\mathrm{c}}$ \\
\hline \multirow[t]{5}{*}{ Sevilla } & 135 & 1 & Manzanilla & $\begin{array}{l}\text { Pseudomonas savastanoi } \mathrm{pv} . \\
\text { savastanoi }\end{array}$ & - & CLRV, P. savastanoi pv. savastanoi \\
\hline & & 2 & Manzanilla & P. savastanoi pv. savastanoi & - & CMV, P. savastanoi pv. savastanoi \\
\hline & & 2 & Manzanilla & P. savastanoi pv. savastanoi & - & SLRSV, P. savastanoi pv. savastanoi \\
\hline & & 4 & Manzanilla & P. savastanoi pv. savastanoi & - & CLRV, SLRSV, P. savastanoi pv. savastanoi \\
\hline & & 34 & Manzanilla & P. savastanoi pv. savastanoi & - & P. savastanoi pv. savastanoi \\
\hline \multirow[t]{10}{*}{ Valencia } & 32 & 1 & Manzanilla RB & 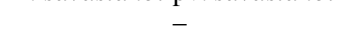 & - & CLRV \\
\hline & & 1 & Arbequina & P. savastanoi pv. savastanoi & - & SLRSV, $P$. savastanoi pv. savastanoi \\
\hline & & 1 & Manzanilla & P. savastanoi pv. savastanoi & - & SLRSV, $P$. savastanoi pv. savastanoi \\
\hline & & 1 & Blanqueta & P. savastanoi pv. savastanoi & - & P. savastanoi pv. savastanoi \\
\hline & & 1 & Oblonga & P. savastanoi pv. savastanoi & - & P. savastanoi pv. savastanoi \\
\hline & & 1 & Hojiblanca & P. savastanoi pv. savastanoi & - & P. savastanoi pv. savastanoi \\
\hline & & 1 & Ascolana tenera & P. savastanoi pv. savastanoi & - & P. savastanoi pv. savastanoi \\
\hline & & 1 & Tomas & P. savastanoi pv. savastanoi & - & P. savastanoi pv. savastanoi \\
\hline & & 1 & Cornicabra & P. savastanoi pv. savastanoi & - & P. savastanoi pv. savastanoi \\
\hline & & 1 & Picual & P. savastanoi pv. savastanoi & - & P. savastanoi pv. savastanoi \\
\hline \multirow[t]{2}{*}{ Córdoba } & 28 & 2 & Manzanilla & P. savastanoi pv. savastanoi & CMV & CMV, P. savastanoi pv. savastanoi \\
\hline & & 2 & Manzanilla & P. savastanoi pv. savastanoi & - & CLRV, $P$. savastanoi pv. savastanoi \\
\hline \multirow[t]{7}{*}{ Barcelona } & 50 & 1 & Aglandau & NT & CLRV & CLRV \\
\hline & & 1 & Empeltre & NT & - & CMV \\
\hline & & 1 & Arbequina & NT & - & CMV \\
\hline & & 1 & Arbequina & NT & - & CLRV \\
\hline & & 1 & Korineiki & NT & - & SLRSV \\
\hline & & 1 & Arbussana & NT & - & SLRSV \\
\hline & & 1 & Leccino & NT & - & SLRSV \\
\hline Total & 245 & 64 & & 56 & 3 & 64 \\
\hline
\end{tabular}

a NT = not tested; $-=$ negative detection.

b CLRV, Cherry leaf roll virus; CMV, Cucumber mosaic virus.

c SLRSV, Strawberry latent ringspot virus. 
$10 \mathrm{~min}$. The pellet was resuspended with $500 \mu \mathrm{l}$ of extraction buffer (200 mM Tris-HCl, pH 7.5; $250 \mathrm{mM} \mathrm{NaCl} ; 25$ mM EDTA; $0.5 \%$ SDS; and $2 \%$ polyvinylpyrrolidone-PVP 10 ), vortexed, and incubated for $1 \mathrm{~h}$ with agitation at room temperature. After centrifugation, supernatant $(450 \mu \mathrm{l})$ was recovered, mixed gently with isopropanol $(450 \mu \mathrm{l})$, and incubated for $1 \mathrm{~h}$ at room temperature. The mixture was centrifuged and the supernatant discarded. The pellet was resuspended in sterile water $(100 \mu \mathrm{l})$ and stored at $-20^{\circ} \mathrm{C}$.

Primers and probes design. Internal primers, for use with those previously described for detection of CMV, CLRV, SLRSV, and ArMV (3), were designed. In addition, internal primers to those previously described (25) for $P$. savastanoi detection were included. Table 2 shows the nucleotide sequence of primers and different digoxigenin-labeled probes designed for the colorimetric detection of amplicons.

Multiplex RT-PCR amplification. Multiplex RT-PCR for CMV, CLRV, SLRSV, and ArMV was performed (3) in a final volume of $25 \mu \mathrm{l}$ consisting of $10 \mathrm{mM}$ Tris- $\mathrm{HCl}(\mathrm{pH} 8.8), 2 \mathrm{mM}$ $\mathrm{MgCl}_{2}, 0.3 \%$ Triton X-100 (wt/vol), $0.1 \mu \mathrm{M} \mathrm{CMV} \mathrm{primers,} 0.3 \mu \mathrm{M}$ CLRV and SLRSV primers, $0.5 \mu \mathrm{M}$ ArMV primers, $0.4 \mu \mathrm{M}$ dNTPs, 5\% dimethyl sulfoxide (DMSO), 5 units of AMV-RT (Promega, San Luis Obispo, CA), 5 units of Taq DNA polymerase (Promega), and $5 \mu \mathrm{l}$ of RNA target. Synthesis of cDNA was performed at $42^{\circ} \mathrm{C}$ for $45 \mathrm{~min}$, and the amplification process was carried out for 40 cycles in a thermal cycler (MasterCycler Gradient; Eppendorf, Hamburg, Germany) under the following conditions: $94^{\circ} \mathrm{C}$ for $30 \mathrm{~s}, 50^{\circ} \mathrm{C}$ for $30 \mathrm{~s}$, and $72^{\circ} \mathrm{C}$ for $2 \mathrm{~min}$. Amplified products were detected by $3 \%$ agarose gel electrophoresis in TE buffer, stained with ethidium bromide, and visualized under UV light or by colorimetric detection.

Nested PCR amplification for $\boldsymbol{P}$. savastanoi. Nested PCR for sensitive $P$. savastanoi detection was performed in a single closed tube as described previously (4). Briefly, the reaction was performed in a final volume of $25 \mu$ consisting of $20 \mathrm{mM}$ Tris- $\mathrm{HCl}$ ( $\mathrm{pH}$ 8.4), $50 \mathrm{mM} \mathrm{KCl}, 2.0 \mathrm{mM} \mathrm{MgCl}_{2}, 3 \%$ formamide, $10 \%$ glycerol, $200 \mu \mathrm{M}$ dNTPs (Amersham Biosciences Europe GmbH, Freiburg, Germany), $0.01 \mu \mathrm{M}$ external primers IAALF and
IAALR (Table 2), $4 \mu \mathrm{M}$ internal primers IAALN1 and IAALN2 (Table 2), 2 units of Taq DNA polymerase (Invitrogen Life Technologies, Groningen, The Netherlands), and $5 \mu \mathrm{l}$ of DNA target. The conditions for amplification were a denaturation step at $94^{\circ} \mathrm{C}$ for $3 \mathrm{~min}$ following by 25 cycles at $94^{\circ} \mathrm{C}$ for $30 \mathrm{~s}, 62^{\circ} \mathrm{C}$ for $30 \mathrm{~s}$, and $72^{\circ} \mathrm{C}$ for $30 \mathrm{~s}$. This first round of amplification was followed by a second round (12) consisting of 40 cycles at $94^{\circ} \mathrm{C}$ for $30 \mathrm{~s}$, $50^{\circ} \mathrm{C}$ for $30 \mathrm{~s}$, and $72^{\circ} \mathrm{C}$ for $30 \mathrm{~s}$. An elongation phase at $72^{\circ} \mathrm{C}$ for $10 \mathrm{~min}$ finished the reaction. Amplified products were detected as described previously. MasterCycler Gradient thermal cycler (Eppendorf) was employed for all amplification reactions.

Nested RT-PCR amplification for viruses. Nested RT-PCR for each virus isolate (CMV, CLRV, SLRSV, and ArMV) was performed in a 0.5-ml Eppendorf tube compartmentalized with the end of a 200- $\mu$ l plastic tip (21). The cocktail for reverse transcription and external amplification was a mixture of $30 \mu$ containing $10 \mathrm{mM}$ Tris- $\mathrm{HCl}(\mathrm{pH} 8.8), 3 \mathrm{mM} \mathrm{MgCl}_{2}, 0.3 \%$ Triton X-100 (wt/vol), $0.3 \mu \mathrm{M}$ dNTPs, $0.01 \mu \mathrm{M}$ each external primer, 5\% DMSO, 3 units of AMV-RT (Promega), 3 units of Taq DNA polymerase (Promega), and $5 \mu$ l of RNA target. This cocktail was dispensed in the bottom of the Eppendorf tube. The internal cocktail containing $10 \mathrm{mM}$ Tris- $\mathrm{HCl}, \mathrm{pH} 8.8$, and $8 \mu \mathrm{M}$ each internal primer was dispensed into the plastic tip where it remained due to capillarity. RT-PCR was carried out in a thermal cycler (MasterCycler Gradient; Eppendorf) at $42^{\circ} \mathrm{C}$ for 45 min followed by a denaturation at $94^{\circ} \mathrm{C}$ for 2 min and 25 cycles of amplification $\left(94^{\circ} \mathrm{C}\right.$ for $30 \mathrm{~s}, 50^{\circ} \mathrm{C}$ for $30 \mathrm{~s}$, and $72^{\circ} \mathrm{C}$ for $\left.1 \mathrm{~min}\right)$. After the first amplification, tubes were vortexed and centrifuged $(7,000 \times g$ for $5 \mathrm{~s})$ to mix the products of the RT-PCR with the cocktail contained in the plastic tip. Nested PCR began with a denaturation phase of $2 \mathrm{~min}$ at $94^{\circ} \mathrm{C}$ followed by 40 cycles of amplification $\left(94^{\circ} \mathrm{C}\right.$ for $30 \mathrm{~s}, 50^{\circ} \mathrm{C}$ for $30 \mathrm{~s}$, and $72^{\circ} \mathrm{C}$ for $1 \mathrm{~min}$ ) (3). Amplified products were detected as described previously.

Multiplex nested RT-PCR amplification. Multiplex nested RT-PCR was performed with a compartmentalized 0.5-ml Eppendorf tube as described in the previous paragraph. The cocktail for reverse transcription and external amplification was a mixture of $30 \mu \mathrm{l}$ containing $10 \mathrm{mM}$ Tris- $\mathrm{HCl}(\mathrm{pH} 8.8) ; 4 \mathrm{mM} \mathrm{MgCl} 2,0.3 \%$

TABLE 2. Sequences of external and internal primers and probes used for detection of Cucumber mosaic virus (CMV), Cherry leaf roll virus (CLRV), Strawberry latent ringspot virus (SLRSV), Arabis mosaic virus (ArMV), and Pseudomonas savastanoi pv. savastanoi

\begin{tabular}{|c|c|c|c|}
\hline Primer/probe ${ }^{\mathrm{a}}$ & Sequence $5^{\prime}-3^{\prime}$ & Position & Amplicon length (bp) \\
\hline CMV 1 & CTTTCTCATGGATGCTTCTC & $1150-1169$ & 885 \\
\hline CMV 2 & GCCGTAAGCTGGATGGAC & 2034-2017 & \\
\hline CMV i1 & ACTATTAАCCACCCAACCT & $1408-1426$ & 172 \\
\hline $\mathrm{CMV}^{*}$ & AATCCTTTGCCGAAATTTGATTCTACCGTGTGGGT & $1588-1622$ & \\
\hline CLRV 1 & CATTTCCATGCGACCGGTCTT & $1433-1453$ & 283 \\
\hline CLRV 2 & AGTCCGACACTCATACAATAAGC & $1715-1693$ & \\
\hline CLRV i1 & GTTAACGAATATCTACTGC & $1497-1515$ & 171 \\
\hline SLRSV 1 & GTTACTTTTACCTCCTCATTGTCCATGTGTTG & $3412-3443$ & 181 \\
\hline SLRSV 2 & GACTATCGTACGGTCTACAAGCGTGTGGCGTC & $3592-3561$ & \\
\hline SLRSV i1 & TGGCCTTTATTGGTTGGAT & $3448-3466$ & 109 \\
\hline SLRSV i2 & ATCTGCCACTGATTCTCAC & $3538-3556$ & \\
\hline SLRSV* & AGTAAGCAGCCGCTAGCGTTCTGGAWTTCCAGGCAYAGTG & $3501-3540$ & \\
\hline ArMV 1 & CGGATTGGGAGTTCGTTGTCG & $2428-2448$ & 340 \\
\hline P. savastanoi pv. savastanoi: IAALF & GGCACCAGCGGCAACATCAA & $1301-1320$ & 454 \\
\hline P. savastanoi pv. savastanoi: IAALR & CGCCCTCGGAACTGCCATAC & $1735-1754$ & \\
\hline P. savastanoi pv. savastanoi: IAALN1 & СТCССТCTCCAACGTCTTC & $1363-1381$ & 338 \\
\hline P. savastanoi pv. savastanoi: IAALN2 & GCCTGATGATTTTCTTCTG & $1682-1700$ & \\
\hline P. savastanoi pv. savastanoi: IAAL* & CTGCCCGGTGATCGCTGCGCCAACCTGTTCACGATCAACCTGTT & $1400-1443$ & \\
\hline
\end{tabular}

${ }^{a}$ Asterisk indicates fluorescent-labeled probe. 
Triton X-100 (wt/vol); $0.4 \mu \mathrm{M}$ dNTPs; $0.01 \mu \mathrm{M}$ CMV, CLRV, SLRSV, ArMV, and P. savastanoi primers (Table 2); 5\% DMSO; 5 units of AMV-RT (Promega); 5 units of Taq DNA polymerase (Promega); $5 \mu \mathrm{l}$ of viral RNA target; and $5 \mu \mathrm{l}$ of bacterial DNA target. The cocktail for the internal amplification was a mixture containing $10 \mathrm{mM}$ Tris- $\mathrm{HCl}, \mathrm{pH} 8.8$, and $8 \mu \mathrm{M}$ each internal primer to CMV, CLRV, SLRSV, ArMV, and P. savastanoi (Table 2) in $10 \mu$ total volume. Multiplex RT-PCR was carried out in a thermal cycler (MasterCycler Gradient; Eppendorf) under the same conditions as indicated previously for conventional nested RT-PCR amplification. Amplified products were detected as described previously.

The sensitivities of multiplex RT-PCR, monospecific nested RTPCR for detection of viruses, and nested PCR for detection of $P$. savastanoi were compared with the sensitivity of multiplex nested RT-PCR for the simultaneous detection of the four viruses and the bacterium. Tenfold serial dilutions of viral RNA and extracted DNA from $P$. savastanoi suspensions were used as templates.

Colorimetric detection. Colorimetric detection was based on the designed 3' digoxigenin-labeled probes, internal to amplified products. Positively charged nylon membranes (Roche Molecular Biochemicals, Mannheim, Germany) were used to bind the amplicons $(1 \mu \mathrm{l})$ through UV light treatment (4 min, $254 \mathrm{~nm})$. Standard buffer consisting of $5 \times \mathrm{SSC}(1 \times \mathrm{SSC}$ is $0.15 \mathrm{M} \mathrm{NaCl}$ plus $0.015 \mathrm{M}$ sodium citrate), $0.1 \%$ (wt/vol) $N$-lauroyl-sarcosine, $0.1 \mathrm{mg} / \mathrm{ml}$ Poly [A] (Sigma), 0.02\% (wt/vol) SDS, and 1\% blocking reagent (Roche) was used for prehybridization $\left(60^{\circ} \mathrm{C}, 1 \mathrm{~h}\right)$ and hybridization $\left(60^{\circ} \mathrm{C}, 2 \mathrm{~h}\right.$; probe at $\left.10 \mathrm{pmol} / \mathrm{ml}\right)$. Colorimetric detection with nitroblue tetrazolium and 5-bromo-4-chloro-3-indolylphosphate substrate was performed by the DIG Nucleic Acid Detection Kit and DIG Wash and Block Buffer Set (Roche) according to the manufacturer's instructions.

\section{RESULTS}

Optimization of nested RT-PCR and multiplex nested RTPCR. Specific amplification products (P. savastanoi, 338 bp; ArMV, 203 bp; CLRV, 172 bp; CMV, 171 bp; and SLRSV, 109 bp) were obtained from all respective positive bacterial and viral controls assayed. No amplification products were obtained from healthy plant extracts or the cocktail control (data not shown).

In the multiplex nested RT-PCR, single or mixed targets were successfully detected (Fig. 1). No definition between bands for CMV and CLRV was observed in Figure 1A (lanes 9 and 10) due to its similar molecular weight. Nevertheless, the specific hybridization of amplified products with their respective probes (Fig. 1B) demonstrated no interference between the different designed primer pairs. In order to optimize the nested RT-PCR reactions for individual detection of RNA targets from CMV, CLRV, SLRSV, and ArMV, various parameters such as the concentration of external $(0.001$ to $1 \mu \mathrm{M})$ and internal $(0.5$ to $2.5 \mu \mathrm{M})$ primers, annealing temperature $\left(45\right.$ to $55^{\circ} \mathrm{C}$ ), and number of cycles (20 to 45 cycles) were evaluated using positive controls as targets. For the first round of amplification using external primers, the best results were obtained with $0.01 \mu \mathrm{M}$ each primer, $50^{\circ} \mathrm{C}$ annealing temperature, and 25 cycles of amplification. For the second round of amplification, the optimal results were obtained with $2 \mu \mathrm{M}$ each internal primer, $50^{\circ} \mathrm{C}$ annealing temperature, and 40 cycles of amplification. For multiplex nested RT-PCR optimization for simultaneous detection of viruses (CMV, CLRV, SLRSV, and ArMV) and $P$. savastanoi bacterium, the parameters evaluated were the concentration of external $(0.001$ to $0.1 \mu \mathrm{M})$ and internal ( 1 to $3 \mu \mathrm{M})$ primers, temperature of annealing $\left(45\right.$ to $55^{\circ} \mathrm{C}$ ), and number of cycles for each round of PCR. The optimal results were obtained using the same conditions previously established for the individual nested RT-PCR: $0.01 \mu \mathrm{M}$ each external primer, $2 \mu \mathrm{M}$ each internal primer, $50^{\circ} \mathrm{C}$ annealing temperature, and 25 cycles for the first round and 40 cycles for the second round of PCR.
Comparison of sensitivities of multiplex nested RT-PCR and multiplex RT-PCR. The sensitivity of multiplex nested RT-PCR was, at least, 100 times greater than the sensitivity of multiplex RT-PCR. Figure 2 shows the comparison of the multiplex RT-PCR and multiplex nested RT-PCR for CLRV and SLRSV, and the comparison of sensitivities of nested PCR and multiplex nested RT-PCR for P. savastanoi. For CLRV, multiplex RT-PCR was able to detect dilutions up to $1: 10^{3}$ (corresponding to a $1: 20,000$, $\mathrm{wt} / \mathrm{vol}$, dilution factor based on weight of plant material/volume of grinding buffer) and multiplex nested RT-PCR detected dilutions up to $1: 10^{5}$ (Fig. 2A). For SLRSV, multiplex RT-PCR detected dilutions up to $1: 10^{2}$, but multiplex nested RT-PCR detected dilutions up to $1: 10^{4}$ (corresponding to $1: 2 \times 10^{5}$ weight of plant material/volume of grinding buffer) as is shown in Figure 2B. For the bacterium, nested PCR and multiplex nested RT-PCR were able to detect DNA targets from $1 \mathrm{CFU} / \mathrm{ml}$ (Fig. 2C).

Detection of viruses (CMV, CLRV, SLRSV, and ArMV) and $P$. savastanoi in olive trees. A total of 245 olive trees were analyzed by nested PCR for P. savastanoi, multiplex RT-PCR (for CMV, CLRV, SLRSV, and ArMV), and multiplex nested RT-PCR (for CMV, CLRV, SLRSV, ArMV, and P. savastanoi) (Table 1).

Nested PCR in a single closed tube using enriched olive tree samples detected $P$. savastanoi in 56 of the tested trees $(28.7 \%)$. The application of multiplex RT-PCR to the same samples detected CMV in two trees and CLRV in one tree. Multiplex nested RTPCR confirmed the presence of amplifiable $P$. savastanoi targets in all trees previously tested positive by enrichment nested PCR. Multiplex nested RT-PCR confirmed infection in three trees previously detected by multiplex RT-PCR. In addition, amplifiable targets from viruses were detected by multiplex nested RT-PCR in 20 samples that previously tested negative by multiplex RT-PCR. Multiplex nested RT-PCR detected CLRV in 10 trees $(4.1 \%)$, SLRSV in 11 trees $(4.5 \%), \mathrm{CMV}$ in 6 trees $(2.4 \%)$, and $P$. savastanoi in 56 trees $(28.7 \%)$. ArMV was not detected in any sample. Mixed infections of CLRV and SLRSV were detected in four trees of cv. Manzanilla (1.6\%) and mixed infections of
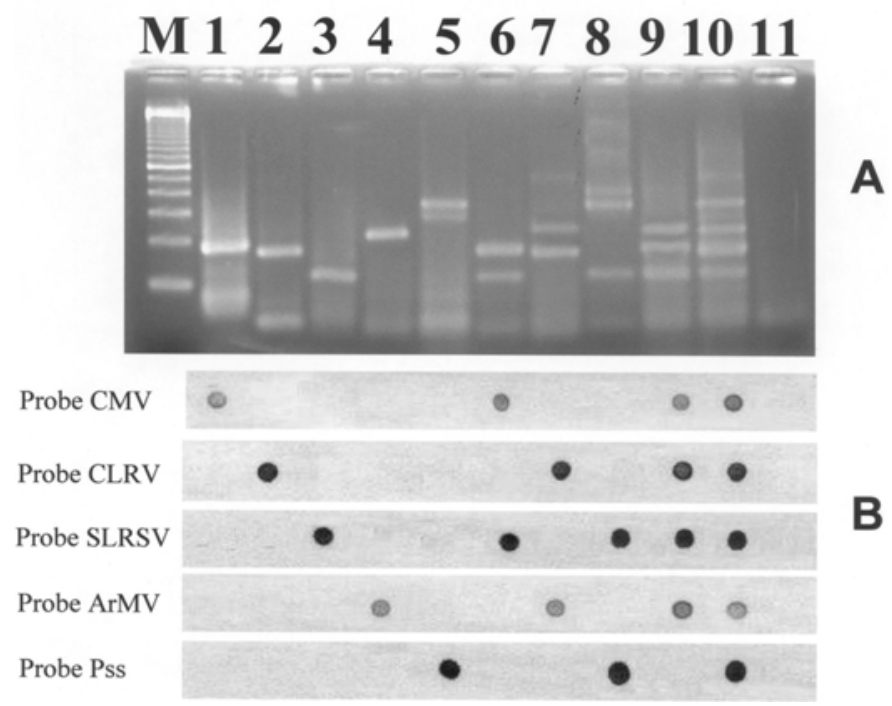

Fig. 1. Detection of four olive viruses and Pseudomonas savastanoi pv. savastanoi by multiplex nested reverse transcription-polymerase chain reaction (RT-PCR). A, Multiplex nested RT-PCR products separated on a $3 \%$ agarose gel, stained with ethidium bromide, and visualized under UV light. B, Colorimetric detection using 3' digoxigenin-labeled probes. Lanes 1 to 5: Cucumber mosaic virus (CMV, 172 bp), Cherry leaf roll virus (CLRV, 171 bp), Strawberry latent ringspot virus (SLRSV, 109 bp), Arabis mosaic virus (ArMV, 203 bp), and P. savastanoi pv. savastanoi (338 bp). Lanes 6 to 10: mixture of CMV + SLRSV, CLRV + ArMV, SLRSV + P. savastanoi pv. savastanoi, CMV + CLRV + SLRSV + ArMV, and CMV + CLRV + SLRSV + ArMV + P. savastanoi pv. savastanoi, respectively. Lane 11: PCR control. Lane M: 100-bp molecular marker (Gibco-BRL). 
viruses along with the bacterium were detected in 15 trees $(7.7 \%)$. Infection with $P$. savastanoi alone was identified in 41 trees out of 64 that tested positive for pathogens. Viral infection was detected in $9.38 \%$ of the tested olive trees.

All olive plants with positive detection for one or more viruses by multiplex nested RT-PCR were submitted to an additional dsRNA extraction (9) in order to confirm viral infection. In some cases, dsRNA was visualized directly in the silver-stained polyacrylamide gel (data not shown). However, in all cases specific amplification products were obtained by multiplex nested RT-PCR using the extracted dsRNA as sample.

Evaluation of different seasons for sampling and analysis of viral distribution in the tree. In spring, CMV, CLRV, and SLRSV infections were detected in eight of nine trees. However, irregular viral distribution was observed when different regions of the canopy were analyzed (Table 3 ). In summer, CLRV infection was detected in one region of the canopy of a single tree. In autumn, CMV and CLRV infection was detected in five of the nine trees, and irregular distribution of the viruses around the canopy of the tree was observed. No trees gave positive amplification in winter. None of the selected trees were positive for viruses throughout the entire canopy within any season.

\section{DISCUSSION}

This newly developed method combines the advantages of the multiplex RT-PCR with the sensitivity and reliability of nested RT-PCR carried out in a single closed tube. This technique enables the detection of several targets in a simultaneous form and permits the detection of viral RNA targets and bacterial DNA targets in a single analysis performed with naturally infected woody plants.

This method could be very useful because different viral and bacterial pathogens may infect one host. It also saves time and reagent costs because it can be performed in a single reaction. The multiplex PCR variants need an accurate design of compatible primers and recently, a methodology to design them, using computer programs that facilitate this task has been described (3). Nucleotide sequences of each virus and the bacterium were retrieved from NCBIs integrated databases (Bethesda, MD), GenBank,
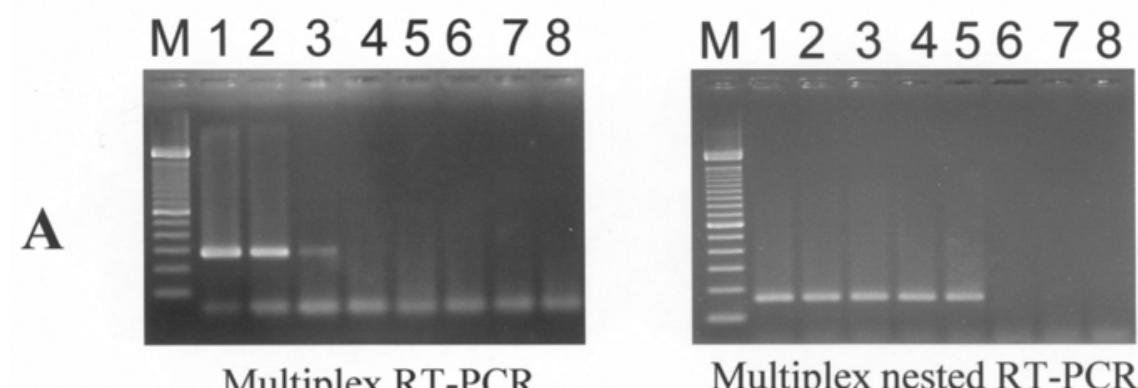

Multiplex RT-PCR

Multiplex nested RT-PCR

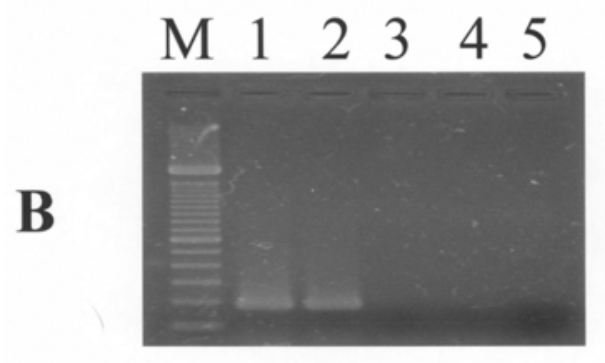

Multiplex RT-PCR

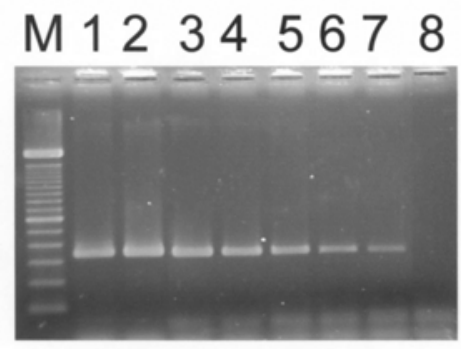

Nested PCR

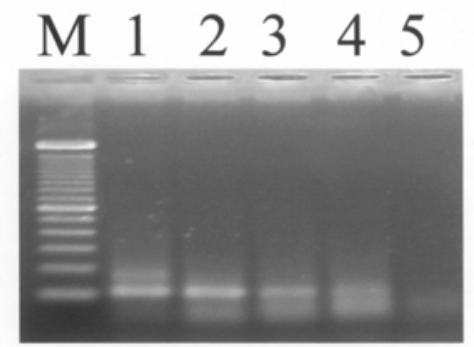

Multiplex nested RT-PCR

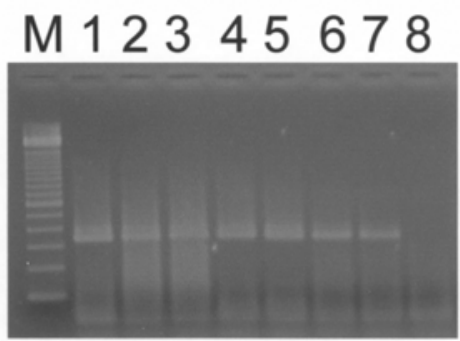

Multiplex nested RT-PCR

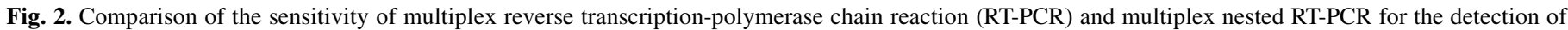

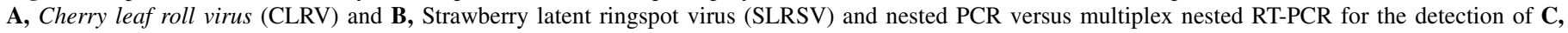

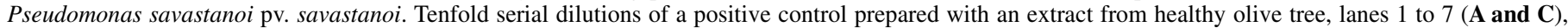
lanes 1 to 4 (B). Cocktail control lane 8 (A and C) and lane 5 (B). Lane M, 100-bp molecular marker (Gibco-BRL). 
EMBL, and DDBJ. To design specific primers and probes able to recognize different isolates and strains, conserved regions for each virus and the bacterium were selected using the similarity search tool Advanced Blast 2.0 (NCBI, Bethesda, MD) for sequence alignment (1). The methodology allowed simultaneous use of up to 20 compatible primers in one reaction and the simultaneous detection of four viruses (CMV, CLRV, SLRSV, and ArMV) and the bacterium $P$. savastanoi in this study.

Plant material often contains inhibitors that reduce the yield of the RT-PCR amplification. Concomitantly, pathogens are often in low titer and uneven distribution in woody hosts. An increase in sensitivity by reamplification of the targets is frequently required (nested or heminested PCR variants) from the products obtained in a first amplification $(17,23)$. The application of the method for the compartmentalization of one Eppendorf tube with a pipette tip (21), allowed the multiplex-PCR and the nested PCR to be combined effectively. During the first amplification reaction there is no interference of the external with internal primers because the internal primers are physically separated from the initial reaction cocktail. Once the multiplex RT-PCR finishes, the internal primers are mixed with the products of the first reaction before proceeding to the nested multiplex. Because the concentration of internal primers is very high compared with that of the external primers

TABLE 3. Detection of olive viruses by multiplex nested reverse transcription-polymerase chain reaction (RT-PCR) in different seasons and regions within the canopy of the tree

\begin{tabular}{|c|c|c|c|c|c|}
\hline Olive tree ${ }^{\mathrm{a}}$ & Region $^{\mathrm{b}}$ & Spring $^{\mathrm{c}}$ & Summer & Autumn & Winter \\
\hline \multirow[t]{4}{*}{1} & A & - & - & - & - \\
\hline & B & CMV & - & CMV & - \\
\hline & $\mathrm{C}$ & - & - & - & - \\
\hline & D & - & - & - & - \\
\hline \multirow[t]{4}{*}{2} & A & SLRSV & - & - & - \\
\hline & B & - & - & - & - \\
\hline & $\mathrm{C}$ & - & - & - & - \\
\hline & D & - & - & - & - \\
\hline \multirow[t]{4}{*}{3} & $\mathrm{~A}$ & - & - & - & - \\
\hline & B & - & - & CMV & - \\
\hline & $\mathrm{C}$ & - & - & - & - \\
\hline & D & - & - & - & - \\
\hline \multirow[t]{4}{*}{4} & A & - & - & - & - \\
\hline & B & CLRV & - & - & - \\
\hline & C & - & - & - & - \\
\hline & D & - & - & - & - \\
\hline \multirow[t]{4}{*}{5} & A & CMV & - & - & - \\
\hline & B & - & - & - & - \\
\hline & $\mathrm{C}$ & - & - & CMV & - \\
\hline & D & - & - & - & - \\
\hline \multirow[t]{4}{*}{6} & A & CLRV & CLRV & CLRV & - \\
\hline & B & CLRV & - & - & - \\
\hline & $\mathrm{C}$ & - & - & - & - \\
\hline & D & - & - & - & - \\
\hline \multirow[t]{4}{*}{7} & A & CMV & - & - & - \\
\hline & B & - & - & - & - \\
\hline & $\mathrm{C}$ & - & - & - & - \\
\hline & D & - & - & - & - \\
\hline \multirow[t]{4}{*}{8} & A & - & - & - & - \\
\hline & B & - & - & - & - \\
\hline & C & CLRV & - & CLRV & - \\
\hline & D & - & - & - & - \\
\hline \multirow[t]{4}{*}{9} & A & SLRSV & - & - & - \\
\hline & B & - & - & - & - \\
\hline & $\mathrm{C}$ & - & - & - & - \\
\hline & $\mathrm{D}$ & - & - & - & - \\
\hline Total & & 8 & 1 & 5 & 0 \\
\hline
\end{tabular}

a Total number of trees from which positive virus sequence amplification was observed out of nine analyzed trees each season.

${ }^{\mathrm{b}} \mathrm{A}, \mathrm{B}, \mathrm{C}$, and D: Four regions representing the canopy of each tree and defined by the structure of the main branches and their directional orientation.

c CMV, Cucumber mosaic virus; SLRSV, Strawberry latent ringspot virus; CLRV, Cherry leaf roll virus; and $-=$ negative detection. (that are also diminished by the first amplification), the nested multiplex can be performed with minimal interference. Consequently, sensitivity is increased at least 100-fold more than in multiplex RT-PCR for the detection of CMV, CLRV, SLRSV, and ArMV viruses (as shown in Figure 2 for CLRV and SLRSV; data not shown for CMV and ArMV). Also, the sensitivity achieved by multiplex nested RT-PCR for the bacterium $P$. savastanoi is similar (Fig. 2C) to the sensitivity reached by applying the monospecific nested PCR after an enrichment step that demonstrated to be 100-fold more sensitive than conventional PCR (25).

The developed multiplex nested RT-PCR has been coupled with colorimetric detection of amplicons using digoxigenin marked internal probes (Fig. 1). Colorimetric detection facilitates the interpretation of results enabling discrimination of amplicons, based on specific hybridization amplicon-target, without the necessity of gel electrophoresis and ethidium bromide staining. In addition, colorimetric detection discriminates easily between CMV (172 bp) and CLRV (171 bp) amplicons of similar size, which would require additional monospecific analysis if only gel visualization was employed (Fig. 1). Amplicon-hybridization allows the identification of all targets, the analysis of many samples in one assay, and an increase of sensitivity, which favors its introduction in routine and certification programs of plant materials (3).

This technique was validated and applied to plant material (245 olive trees from the FAO collection) where it confirmed all positive samples detected by multiplex RT-PCR and detected additional viral infections not detected by multiplex RT-PCR. Targets from CLRV were amplified from 0.4 to $4.1 \%$ of the trees, CMV from 0.8 to $2.4 \%$, and SLRSV from 0 to $4.5 \%$ when analyzed by multiplex RT-PCR or multiplex nested RT-PCR, respectively. The method had identical success in detecting $P$. savastanoi $(28.7 \%$ of the analyzed trees) compared with the monospecific nested PCR.

This sensitive method was applied to the evaluation of spatial and temporal distribution of some viruses in adult olive trees. The results (Table 3) show an uneven distribution of the tested pathogens in trees. Not a single infected tree presented positive detection throughout the canopy. Consequently, sampling of no less than five samples per adult tree is recommended for routine detection. No correlation between positive regions of the tree and their directional orientation was established (Table 3). In addition, the sampling period seems to be critical for the assayed virus because no single analyzed tree gave positive amplification in all assayed vegetative periods. Spring supplied the highest detection levels (eight of nine trees), in agreement with previous observations (9). In $50 \%$ of the trees, coincidental positive detection was evident in spring and autumn. No positive amplification from the assayed infected trees was observed in winter, probably due to a low viral titer during latency of olive trees.

The developed methodology provides cost-effective analysis and can easily be applied to other models after this demonstration of its feasibility, reliability, and sensitivity, specifically in detecting several pathogens in one assay without primer interference.

\section{ACKNOWLEDGMENTS}

This work was supported by grants OLI96-2179 from CICYT, SC98060 from INIA, and project 1FD 1997-2279 from the Spanish Ministerio de Ciencia y Tecnología. E. Bertolini was recipient of a Ph.D. fellowship from Agencia Española de Cooperación Internacional. We thank J. Caballero and C. del Río from CIFA-Córdoba, M. P. Suarez from University of Sevilla, and A. Minguez from Consellería de Agricultura, Pesca y Alimentación de la Generalidad Valenciana, Valencia, Spain, for providing olive tree samples; M. Luis from SIA-Zaragoza, Spain, P. Gentit from CTIFL-Bergerac, France, and G. Martelli from University of Bari-Italy for supplying positive controls; L. G. Ferri from Cotevisa and J. Pinochet from Agromillora Catalana S.A. for supplying samples and healthy olive controls; and D. Donnellan and F. Barraclough for critically reading the manuscript. 


\section{LITERATURE CITED}

1. Altschul, S. F., Madden, T. L., Schäfer, A. A., Zhang, J., Zhang, Z., Miller, W., Myers, E. W., and Lipman, D. J. 1997. Gapped BLAST and PSI-BLAST: A new generation of protein database search programs. Nucleic Acids Res. 25:3389-3402.

2. Bariana, H. S., Shannon, A. L., Chu, P. W. G., and Waterhouse, P. M. 1994. Detection of five seedborne legume viruses in one sensitive multiplex polymerase chain reaction test. Phytopathology 84:1201-1205.

3. Bertolini, E., Olmos, A., Martínez, M. C., Gorris, M. T., and Cambra, M. 2001. Single-step multiplex RT-PCR for simultaneous and colourimetric detection of six RNA viruses in olive trees. J. Virol. Methods 96:33-41.

4. Bertolini, E., Penyalver, R., García, A., Olmos, A., Quesada, J. M., Cambra, M., and López, M. M. 2003. Highly sensitive detection of Pseudomonas savastanoi pv. savastanoi in asymptomatic olive plants by nested-PCR in a single closed tube. J. Microbiol. Methods. 52:261-266.

5. Dodds, J. A. 1993. dsRNA in diagnosis. Pages 274-294 in: Diagnosis of Plant Virus Diseases. R. E. F. Matthews, ed. CRC Press, Boca Raton, FL.

6. Gardan, L., Bollet, C., Ghorrah, M., Grimont, F., and Grimont, P. A. D. 1992. DNA relatedness among the pathovar strains of Pseudomonas syringae subsp. savastanoi Janse (1982) and proposal of Pseudomonas savastanoi sp. Int. J. Syst. Bacteriol. 42:606-612.

7. Garnsey, S. M., and Cambra, M. 1991. Enzyme-linked immunosorbent assay (ELISA) for citrus pathogens. Pages 193-216 in: Graft-Transmissible Diseases of Citrus. Handbook for Detection and Diagnosis. C. N. Roistacher, ed. FAO, Rome.

8. Gorris, M. T., Cambra, M., Leconte, P., Llop, P., Chartier, R., Paulin, J. P., and López, M. M. 1996. A sensitive and specific detection of Erwinia amylovora based on the ELISA-DASI enrichment method with monoclonal antibodies. Acta Hortic. 411:41-46.

9. Grieco, F., Alkowni, M., Saponari, V., Savino, V., and Martelli, G. P. 2000. Molecular detection of olive viruses. EPPO Bull. 30:469-473.

10. Grieco, F., and Gallitelli, D. 1999. Multiplex reverse transcriptase chain reaction applied to virus detection in globe artichoke. J. Phytopathol. 147:183-185.

11. King, E., Ward, O., and Raney, D. E. 1954. Two simple media for the demonstration of pyocyanin and fluorescein. J. Lab. Clin. Med. 44:301307.

12. Llop, P., Bonaterra, A., Peñalver, J., and López, M. M. 2000. Development of a highly sensitive nested-PCR procedure using a single closed tube for detection of Erwinia amylovora in asymptomatic plant material. Appl. Environ. Microbiol. 66:2071-2078.

13. Llop, P., Caruso, P., Cubero, J., Morente, C., and López, M. M. 1999. A simple extraction procedure for efficient routine detection of pathogenic bacteria in plant material by polymerase chain reaction. J. Microbiol. Methods 37:23-31.

14. López-Escudero, F. J., and Blanco-López, M. A. 1999. First report of transmission of Verticillium dahliae by infested manure in olive orchards in Andalusia (Southern Spain). Plant Dis. 83:1178.

15. Menzel, W., Jelkmann, W., and Maiss, E. 2002. Detection of four apple viruses by multiplex RT-PCR assays with coamplification of plant mRNA as internal control. J. Virol. Methods 99:81-92.
16. Minafra, A., and Hadidi, A. 1994. Sensitive detection of grapevine virus A, B or leafroll-associated virus III from viruliferous mealybugs and infected tissue. J. Virol. Methods 47:175-187.

17. Mutasa, E. S., Chwarszczynska, D. M., and Asher, M. J. C. 1996. Singletube, nested PCR for the diagnosis of Polymyxa betae infection in sugar beet roots and colorimetric analysis of amplified products. Phytopathology 86:493-497.

18. Nemichov, L., Hadidi, A., Candresse, T., Foster, J. A., and Verderevskaya, T. 1995. Sensitive detection of apple chlorotic leaf spot virus from infected apple or peach tissue using RT-PCR, IC-RT-PCR or multiplex IC-RT-PCR. Acta Hortic. 386:51-62.

19. Nie, X., and Singh, R. P. 2001. A novel usage of random primers for multiplex RT-PCR detection of virus and viroid in aphids, leaves, and tubers. J. Virol. Methods 91:37-49.

20. Okuda, M., and Hanada, K. 2001. RT-PCR for detecting five distinct Tospovirus species using degenerate primers and dsRNA template. J. Virol. Methods 96:149-156.

21. Olmos, A., Cambra, M., Esteban, O., Gorris, M. T., and Terrada, E. 1999. New device and method for capture, reverse transcription and nested PCR in a single closed-tube. Nucleic Acids Res. 27:1564-1565.

22. Olmos, A., Dasi, M. A., Candresse, T., and Cambra, M. 1996. Printcapture PCR: A simple and highly sensitive method for the detection of plum pox virus (PPV) in plant tissues. Nucleic Acids Res. 24:2192-2193.

23. Orou, A., Fechner, B., Menzel, J. H., and Utermann, G. 1995. Automatic separation of two PCRs in one tube by annealing temperature. Trends Genet. 11:127-128.

24. Osiowy, C. 1998. Direct detection of respiratory syncytial virus, parainfluenza virus, and adenovirus in clinical respiratory specimens by a multiplex reverse transcription-PCR assay. J. Clin. Microbiol. 36:31493154.

25. Penyalver, R., Garcia, A., Ferrer, A., Bertolini, E., and López, M. M. 2000. Detection of Pseudomonas savastanoi pv. savastanoi in olive plants by enrichment and PCR. Appl. Environ. Microbiol. 66:2673-2677.

26. Saade, M., Aparicio, F., Sánchez-Navarro, J. A., Herranz, M. C., Myrta, A., Di Terlizzi, B., and Pallás, V. 2000. Simultaneous detection of the three ilarviruses affecting stone fruit trees by nonisotopic molecular hybridization and multiplex reverse transcription-polymerase chain reaction. Phytopathology 90:1330-1336.

27. Savino, V., Barba, M., Gallitelli, D., and Martelli, G. P. 1979. Two nepoviruses isolated from olive in Italy. Phytopathol. Mediterr. 18:135-142.

28. Savino, V., and Gallitelli, D. 1981. Cherry leaf roll virus in olive. Phytopathol. Mediterr. 20:202-203.

29. Savino, V., and Gallitelli, D. 1983. Isolation of cucumber mosaic virus from olive in Italy. Phytopathol. Mediterr. 22:76-77.

30. Smith, E. F., and Rorer, J. B. 1904. The olive tubercule. Science 19:416417.

31. Surico, G., and Lavermicocca, P. 1989. A semiselective medium for the isolation of Pseudomonas syringae pv. savastanoi. Phytopathology 79:185-190

32. Wetzel, T., Candresse, T., Macquaire, G., Ravelonadro, M., and Dunez, J. 1992. A highly sensitive immunocapture polymerase chain reaction method for plum pox potyvirus detection. J. Virol. Methods 39:27-37. 